\title{
Importance of benthic productivity in controlling the flux of dissolved inorganic nitrogen through the sediment-water interface in a hypertrophic marine ecosystem
}

\author{
M. D. Krom* \\ National Institute of Oceanography, Israel Oceanographic \& Limnological Research, POB 8030, Tel Shikmona, Haifa, Israel
}

\begin{abstract}
The rate of bacterial nitrate reduction measured directly in sediments from a hypertrophic marine ecosystem $\left(6.0 \pm 1.5 \mathrm{mmol} \mathrm{m}^{-2} \mathrm{~d}^{-1}\right)$ was similar to the value calculated from a whole pond

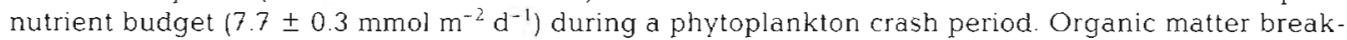
down in the sediments represented the dominant source of ammonia- $\mathrm{N}$ to the system $\left(16.09 \mathrm{mmol} \mathrm{\textrm {m } ^ { - 2 }}\right.$ $\mathrm{d}^{-1}$ compared to $2.97 \mathrm{mmol} \mathrm{m} \mathrm{m}^{-2} \mathrm{~d}^{-1}$ directly from fish excretion and $0.28 \mathrm{mmol} \mathrm{m}^{-2} \mathrm{~d}^{-1}$ in the inflow\}. However most, if not all, of this ammonia- $\mathrm{N}$ did not reach the water column as shown by a total nutrient budget for the pond. It was intercepted by the benthic flora and used to support high levels of benthic productivity $\left(246 \mathrm{mmol} \mathrm{O} \mathrm{m}^{-2} \mathrm{~d}^{-1} ; 29.72 \mathrm{mmol} \mathrm{N} \mathrm{m} \mathrm{m}^{-1}\right)$. The benthic productivity was calculated by correcting the total system gross production (determined by a total oxygen budget) for water column productivity measured by in situ incubated light/dark bottles. It is suggested that benthic productivity by micro- and macroalgae may be important in a number of shallow water systems as modifiers of the flux of ammonia- $\mathrm{N}$ from the sediment to the overlying waters.
\end{abstract}

\section{INTRODUCTION}

One of the most important and yet difficult processes to quantify in shallow marine ecosystems is the flux of metabolites across the sediment-water interface (Nixon 1981, Hammond et al. 1985). One method which has been used to examine this process has been to measure the pore water profile of the metabolite of concern and calculate the flux to the overlying water using Fick's 1st law (Billen 1978, Hammond et al. 1985, Mackin \& Swinder 1989). This procedure, however, determines the flux to the sediment-water interface but not necessarily across it, since it has been shown that in shallow marine systems with sufficient light penetration, benthic productivity can significantly modify the flux of nutrients out of the sediment (Henriksen et al. 1980, Blackburn \& Henriksen 1983, Sundbäck \& Granéli 1988). This approach also misses the

\footnotetext{
- Present address: Department of Earth Sciences, Leeds University, Leeds LS2 9JT, United Kingdom
}

highly reactive floc which is often present at the sediment-water interface. Previous studies which have tried to take into account benthic productivity have generally isolated the sediment in benthic chambers in situ and then measured the change in the concentration of the dissolved nutrient over several hours in the light and the dark (e.g. Nowicki \& Nixon 1985a, Asmus 1986). In such studies care is generally taken to exclude macroalgae (and macrobenthos and fish) from the chamber. Yet other studies have shown that macroalgae can make a major contribution to the total community productivity in such ecosystems (Nixon 1982, Nowicki \& Nixon 1985b, Cahoon \& Cooke 1990). In this study measurements were made of the rates of nitrate reduction, nitrification and ammonia- $\mathrm{N}$ production in the sediment and dissolved oxygen production and respiration in the water column. These data were then compared to and reconciled with the total external budgets for nitrate, ammonia- $\mathrm{N}$ and dissolved oxygen for a whole pond system. By this means it was possible to determine the rate of nitrate reduction in 
the system as a whole and the effect of benthic productivity, both macro + micro, on the flux of ammonia$N$ from the sediment to the overlying water.

The pond studied was an extreme hypertrophic ecosystem, an experimental marine fishpond. It has a high input of nutrients from the inflow and from the fish food (Krom et al. 1985a). Some of the highest rates of sulphate reduction ever measured in a marine ecosystem ( 70 to $90 \mathrm{mmol} \mathrm{m}^{-2} \mathrm{~d}^{-1}$ ) have been measured in the sediments of this pond (Blackburn et al. 1988). Many eutrophic and hypertrophic systems, such as sewage outfalls, mariculture seacages or mussel rafts, polluted estuaries and embayments, and fishponds, have elevated rates of organic matter decomposition in the sediments (Tenore et al, 1982, Blackburn et al. 1988, Westrich \& Berner 1989, Hall et al. 1990). They are also frequently located in water shallow enough that light can penetrate to the sediment-water interface in sufficient amounts to support benthic primary productivity (Nixon et al. 1975, Nixon 1982). Thus, the results of this study, while carried out on an extreme system, are of relevance to a number of important, relatively less extreme, natural and polluted ecosystems,

Many processes are known to affect the dynamics of ammonia and nitrate in eutrophic marine systems. While the nature of many of these processes is known in considerable detail, relatively few studies have set out to examine the interaction of several processes simultaneously and their relative importance to nutrient dynamics in a complete ecosystem. In this study, while concentrating on the effect of benthic productivity on the flux of nutrients through the sedimentwater interface, the relative importance of several of the major processes affecting ammonia- $\mathrm{N}$ and nitrate dynamics was estimated.

\section{MATERIALS AND METHODS}

Description of the pond ecosystem. The experimental fishpond used in this study was situated in Eilat, Israel, on the Gulf of Eilat (Aqaba). The pond was rectangular with a surface area of $325 \mathrm{~m}^{2}$ and a volume of $175 \mathrm{~m}^{3}$. Its average depth was $0.54 \mathrm{~m}$, with a maximum depth in the central axis of 0.9 to $1.0 \mathrm{~m}$. The pond was diluted with seawater from a well at a rate of $3 \mathrm{~m}^{3}$ $h^{-1}$ which resulted in a dilution rate of 0.41 pond $d^{-1}$. At this flow rate, the salinity increased from 39.95 ppt in the inlet to $41.40 \mathrm{ppt}$ in the pond due to evaporation. The pond was supplied with water pumped from a nearby seawater well. The well water had a large component (70 to $80 \%$ ) of recycled pond water, a small sewage component (ca $10 \%$ ) with the remainder being fresh seawater from the adjacent Gulf of Eilat
(Krom 1986). The inflowing water had reduced oxygen and $\mathrm{pH}$ values $(160 \mu \mathrm{M}$ and 7.8 respectively; Erez et al. 1990). It also contained high levels of nitrate + nitrite (ca $40 \mu \mathrm{M}$ ), silicate (ca $120 \mu \mathrm{M}$ ) and phosphate (ca 1.2 $\mu \mathrm{M})$. The pond was originally constructed of coarse sand and gravel. A lining of fine silt was then placed inside to seal the pond which was then covered with a further layer of $20 \mathrm{~cm}$ of coarse sand. During the period of operation of the pond the coarse sand and silt had become somewhat mixed.

The pond was dried for 4 wk in August 1985, and then filled with seawater from the well. It was stocked with 800 gilthead seabream Sparus aurata of average weight $2 \mathrm{~g}$ and 150 small (5 to $10 \mathrm{~g}$ ) mullet (Mugilidae). At the time of this study, the range of weight of the fish. was 30 to $45 \mathrm{~g}$. The fish were fed daily $550 \mathrm{~g}$ of artificial fish food containing $53.3 \% \mathrm{C}, 6.9 \% \mathrm{~N}$ and $1.25 \%$ $\mathrm{P}$ (Krom et al. 1985a). This corresponds to an input rate of $8.3 \mathrm{mmol} \mathrm{N} \mathrm{m}^{-2} \mathrm{~d}^{-1}$. The high levels of dissolved nutrients supplied from the well to the pond support high algal biomass and productivity. The phytoplankton, which were mainly diatoms (Chaetoceras sp., Thallassiosira sp.), showed bloom and crash cycles on a periodicity of ca $1 \mathrm{mo}^{-1}$ (Motzkin et al. 1982, Krom et al. 1989). The crashes were caused by microflagellate grazing (Neori unpubl.). There were no macrozooplankton in the system. The benthic microalgae were mainly diatoms and cyanobacteria, and the macroalgae principally Enteromorpha and less abundantly Ulva. In addition there were abundant benthonic macrofauna, associated particularly with the macroalgae, of amphipods, copepods, palaemon shrimps and polychaetes. $S$. aurata is a carnivorous fish known to feed in nature mainly on molluscans and crustaceans, Mugilidae feed on detritus.

Sampling and analysis. The inlet was sampled for dissolved nutrients at high and low tide and the average value calculated. The dissolved nutrients in the pond were collected by sampling a continuously flowing syphon situated near the outflow at 08:00 h and again at 16:00 h. The results given here are the average of the 2 values obtained. Previous studies have shown the pond waters to be well mixed and that the daily average nutrient content can be satisfactorily estimated from the average of these 2 samples (Krom et al. 1989). The water samples were filtered through $0.45 \mu \mathrm{m}$ Millipore filters and stored in iodized plastic bottles at $4^{\circ} \mathrm{C}$ for a maximum of $3 \mathrm{~d}$ before analysis. Nitrate + nitrite was determined on a Technicon Autoanalyzer II using a $\mathrm{Cd}$ reduction method (Glibert \& Loder 1977). Total dissolved ammonia- $N$ was determined using an automated phenol-hypochlorite method (Krom et al. 1985b). The precision (95\% confidence limits) for these determinations was $0.3 \%$ (nitrate + nitrite) and $2.0 \%($ ammonia- $N)$. The samples 
for chlorophyll were collected from the syphon at 14:00 h each day. Samples were collected on GF/C filters and frozen for a minimum of $24 \mathrm{~h}$ and a maximum of 3 wk before extraction and immediate analysis. Chlorophyll a (and phaeophytin) were determined using the acetone extraction procedure given in Strickland \& Parsons (1972). The equations used to determine the chlorophyll pigment were those of Parsons \& Strickland as quoted in Strickland \& Parsons (1972).

Dissolved oxygen was determined continuously by means of a sensor package mounted on a PVC pole which was deployed in the center line of the pond. It included a temperature (thermistor) sensor, and oxygen and $\mathrm{pH}$ electrodes. A small submerged electrical pump was used to stir the water next to the electrodes. The oxygen sensor was calibrated daily in airsaturated seawater. In addition during several $24 \mathrm{~h}$ periods, Winkler oxygen samples were taken and the sensitivity of the sensors recalculated on the basis of the results obtained. Measurements were made in the pond and in the inlet to the pond. The sensor package was attached to a computer and the resulting Data Acquisition System (DAS) was operated for 26 d between 10 February and 3 April 1986 (Erez et al. 1990).

The details of the calculations involved in the dissolved oxygen budget and their mathematical formulation are given in Erez et al. (1990). Briefly, the calculation is based on the following rate equation:

$$
\mathrm{d} O / \mathrm{d} t=P+R+E+D
$$

where $\mathrm{d} O / \mathrm{d} t=$ rate of oxygen production or consumption (as measured by the DAS), and $P$ and $R=$ gross photosynthesis and respiration, respectively, for the entire community. $E$ = rate of exchange of oxygen with the atmosphere which is calculated from the deviation of oxygen levels from saturation, assuming simple diffusion across the air-water interface. $D=$ dilution rate of oxygen caused by the difference in oxygen concentration between the water flowing into and out of the ponds. This formulation is essentially similar to that introduced by Odum (1956) for flowing waters and used by Olah et al. (1978) for freshwater fish ponds. Initially $R$ was calculated for the night time when there is no photosynthesis. Gross primary productivity was calculated using Eq. (1) and assuming the average night time respiration rate was valid for the day period. The oxygen derivative was estimated by differentiation of a 6 to 8 order polynomial fit (obtained using SIGMAPLOT) of the raw dissolved oxygen data.

A study of many of the microbial processes affecting $\mathrm{C}$ and $\mathrm{N}$ mineralization in the sediments of this pond was conducted at this time $(30$ March to 4 April). A brief description of the methodology of those experiments which are used directly in this study follows. For a detailed description of the procedures used the reader is refered to Blackburn et al. (1988). The pond which is the subject of this study is referred to as pond \#6 in Blackburn et al. (1988).

Denitrification rates were measured in 4 (replicate) sediment cores. The sediment and overlying water (inlet water from the well) were spiked with acetylene to inhibit reduction of $\mathrm{N}_{2} \mathrm{O}$ to $\mathrm{N}_{2}$. The cores were incubated in the dark at ambient pond temperature, the accumulation of $\mathrm{N}_{2}$ in the overlying water and the sediment measured, and the rate of denitrification calculated.

Potential nitrification rates were measured by incubating surface sediment saturated with ammonia- $N$ and dissolved oxygen.

Rates of ammonia- $\mathrm{N}$ production in the sediment were made by incubating sediment blended together anaerobically with ${ }^{15} \mathrm{NH}_{4} \mathrm{Cl}$ to give $10 \%$ enrichment. The sediment samples were incubated for $0,1,2$ and 3 $\mathrm{d}$ at ambient pond temperature and then extracted for both pore water ammonia-N and subsequently for ${ }^{15} \mathrm{NH}_{4}{ }^{+}$content. Sulphate reduction rates were measured by incubation of the sediment for $4 \mathrm{~h}$ at ambient pond temperature after being spiked with ${ }^{35} \mathrm{SO}_{4}$. Zinc chloride was added to the sediment to ensure that all free sulphide was trapped and subsequently analysed for acid-volatile total sulphide and radiolabelled sulphide.

During selected periods, primary productivity of the water column was measured using changes in oxygen levels in light/dark bottles held at fixed depths in the pond (Strickland \& Parsons 1972). Incubations were carried out at $10,30,50,70$ and $90 \mathrm{~cm}$ depths for periods of 2 to $3 \mathrm{~h}, 3$ times a day begining at 08:30 h and finishing in the late afternoon. Dissolved oxygen was measured by Winkler titration (Strickland \& Parsons 1972) Net productivity was obtained by integrating the changes in oxygen concentration over the total period of light and over the known volume of each depth interval in the pond. Light profiles were determined using a LICOR light meter.

\section{RESULTS}

From 30 January until 8 April 1986 there were large changes in water column chlorophyll a concentrations with peak (bloom) levels in excess of $60 \mu \mathrm{g} \mathrm{l}^{-1}$ at the beginning and end of the sampling period (Fig. 1). During the bloom period ammonia-N was low $(<1 \mu \mathrm{M})$ and nitrate+nitrite was zero. During the period from 18 February until 24 March the pond had relatively low, though fluctuating, levels of chlorophyll and corres- 


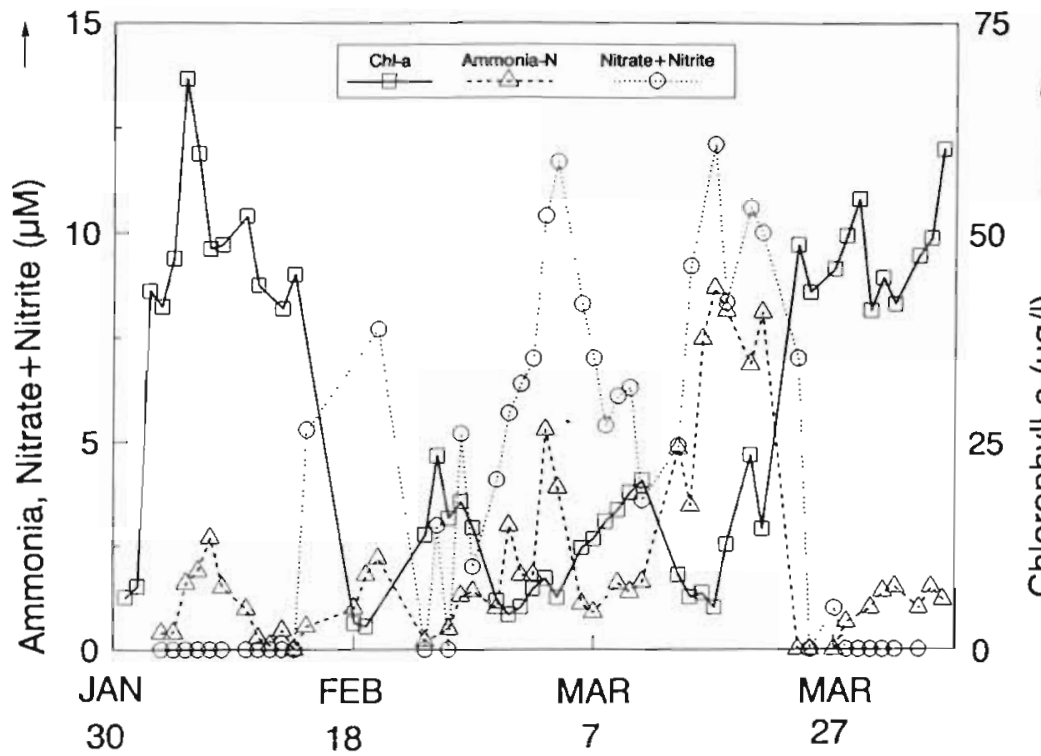

Fig. 1. Average daily chlorophyll a, ammonia- $N$ and nitrate + nitrite concentrations in the pond from 30 January (Day 0) until 8 April 1986

pondingly higher levels of ammonia- $N$ and nitrate+ nitrite. The average concentration of ammonia- $N$ in the inflow during the period 3 March to 7 April was 0.8 $\pm 0.1 \mu \mathrm{M}$ and that for nitrate+nitrite was $42 \pm 0.9 \mu \mathrm{M}$. The dissolved oxygen and temperature profiles for the pond used in this study are shown in Figs. 1 \& 3 (Pond 6) of Erez et al. (1990).

The light profile in the water column measured on 30 March (bloom period) at midday showed an extinction coefficient of $0.006 \mathrm{~cm}^{-1}$. At that time light levels greater than $5 \%$ were incident over the entire sediment of the pond and $80 \%$ of the bottom of the pond received greater than $10 \%$

\section{Nutrient budget calculations}

Conceptual model used for nitrate budget. All the possible major processes involved in the nitrate budget are shown in Fig. 2:

Sources of nitrate to the pond:

(1) Inflow.

(2) Oxidation of organic matter in the water column directly to nitrate.

(3) Nitrification in the water column.

(4) Nitrification in the surficial sediment.

Sinks of nitrate in the pond:

(1) Outflow

(2) Phytoplankton uptake

(3) Sedimentary nitrate reduction.

Of these processes, the inflow and outflow were measured directly (Fig, 2). The rate of nitrate reduction in the sediment was measured directly by a specific experiment and was also calculated by difference in the total nitrate budget
If nitrification was an important process in the water column of the pond, a peak of nitrite would have been observed as the ammonia- $N$ decreased, as has been observed in other hypertrophic systems such as freshwater fishponds (Rimon \& Shilo 1982). No such peak was observed either in this study (Fig. 1) nor in previous observations in these ponds (Krom et al. 1989). Furthermore direct measurements of the potential nitrification rate in the surface sediments of the pond at this time indicated a total absence of this activity (Blackburn et al. 1988)

Organic matter decomposition directly to nitrate in the water column, even under oxic conditions such as were found in the pond, is generally considered to be

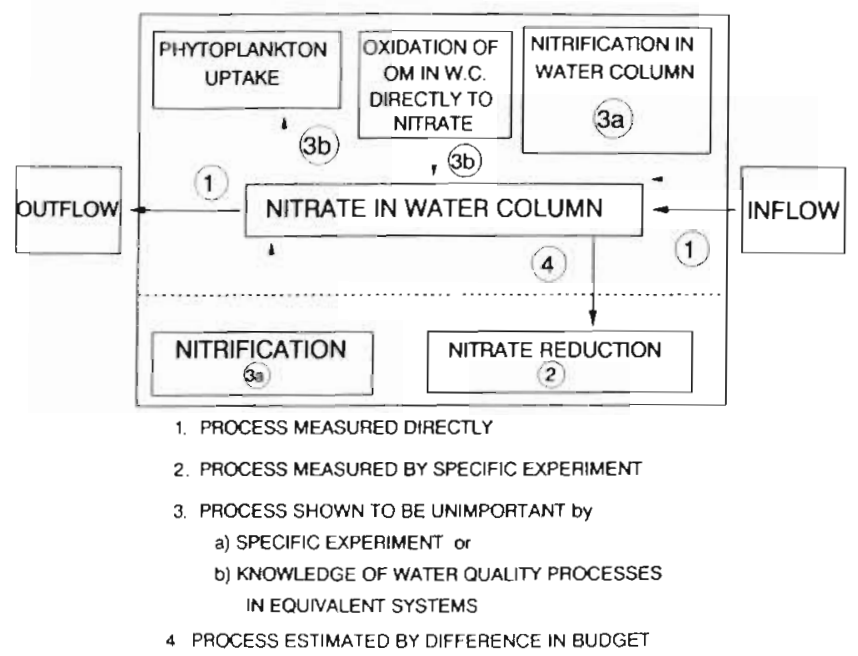

Fig. 2. Conceptual model used showing the major processes considered in the nitrate budget of the pont and how they were determined in this system. 
an unimportant process (Blackburn pers. comm.) and was thus ignored in calculating the nitrate budget for the pond.

During the crash period, high levels of ammonia-N and comparatively low levels of chlorophyll were measured in the water column. Under such conditions, phytoplankton in these ponds take up ammonia-N preferentially to nitrate (Krom et al. 1989) as has been shown previously in other marine systems in both laboratory and field studies (Goldman 1976, Berman et al. 1984).

Thus during the phytoplankton crash period the nitrate budget simplifies to:

$$
\text { Net nitrate reduction }=\text { Inflow }- \text { Outflow }
$$

where net nitrate reduction is equal to the bacterial sedimentary nitrate reduction. Inflow and Outflow are calculated from the average daily concentration measured in the inlet and outlet of the pond multiplied by flow rate of water out of the pond.

During the period from 3 to 24 March 1986 the calculated net nitrate reduction rate was $2490 \mathrm{mmol} \mathrm{N}$ pond $\mathrm{d}^{-1} \mathrm{~d}^{-1}$ This is equivalent to a rate of $7.7 \pm 0.3$ $\mathrm{mmol} \mathrm{N} \mathrm{m}^{-2} \mathrm{~d}^{-1}$ over the entire area of the pond (Table 1). The errors were estimated as the standard error of

Table 1 . Sources and sinks of nitrate to the pond during a phytoplankton crash period (6 to 24 March 1986). All values are given in $\mathrm{mmol} \mathrm{m} \mathrm{m}^{-2} \mathrm{~d}^{-1}$ using a pond area of $325 \mathrm{~m}^{2} \pm \mathrm{SE}$ of mean; $\mathrm{n}=21$

\begin{tabular}{|ccc|}
\hline Inflow & Outflow & $\begin{array}{c}\text { Sediment nitrate } \\
\text { reduction rate } \\
\text { (Whole pond estimate) }\end{array}$ \\
\hline $9.29 \pm 0.3$ & $1.63 \pm 0.12$ & $7.66 \pm 0.26$ \\
\hline
\end{tabular}

the mean for these values obtained on each of 21 successive days (Inflow, Outflow, and Inflow-Outflow).

A similar budget was not calculated for the bloom period since it was known that at that time nitrate is removed from the water column by phytoplankton uptake (Krom et al. 1989). The interelationships between nitrate, ammonia and DON uptake were not sufficiently well quantified to enable such a budget to be calculated without large uncertainties being involved.

Conceptual model for ammonia budget in the pond. Fig. 3 represents all the major processes of importance in the budget of ammonia- $\mathrm{N}$ in the pond.

The possible sources of ammonia- $\mathrm{N}$ to the water column are:
(1) Inflow.
(2) Fish excretion.
(3) Excretion by grazing micro-organisms.

(4) Excretion by benthic macrofauna.

(5) Bacterial decomposition of organic matter in the water column.

(6) Bacterial decomposition of organic matter in the sediment.

The possible sinks of ammonia- $\mathrm{N}$ in the system are:

(1) Outflow.

(2) Phytoplankton uptake.

(3) Uptake at the sediment-water interface by benthic primary productivity.

(4) Nitrification in the water column and/or sediment.

The inflow, outflow and phytoplankton uptake were determined from measurements made directly on the pond system (Fig. 3). The concentration of ammonia-N in water flowing into and out of the pond was measured twice daily and the flux calculated from the mean concentration multiplied by the flow rate.

The uptake of ammonia- $\mathrm{N}$ by phytoplankton was estimated from the flux of chlorophyll a out of the pond. An N/chl ratio of $0.64(\mu \mathrm{mol} N / \mu g$ chl a) was used. This ratio was estimated from the slope of the ammonia- $N$ vs chlorophyll a curve during the rapid phytoplankton growth phase as the pond went from crash to bloom conditions when the pond was operated under similar conditions in 1985 (Ellner et al. 1988). This ratio is within the range of values considered reasonable for healthy phytoplankton $(0.4 \mu \mathrm{mol}$ N/ug chl a; Parsons et al. 1984). The errors shown in Table 2 for the inflow, outflow and phytoplankton uptake were calculated as the standard error of the mean for data collected on 19 days during the period 3 to 24 March. The calculated net removal of ammonia$\mathrm{N}$ from the pond by phytoplankton uptake for the period ( 3 to 24 March 1986) was $1.63 \pm 0.18 \mathrm{mmol} \mathrm{N}$ $\mathrm{m}^{-2} \mathrm{~d}^{-1}(\mathrm{SE}, \mathrm{n}=21)$. If the $\mathrm{N} / \mathrm{chl}$ ratio was wrong by
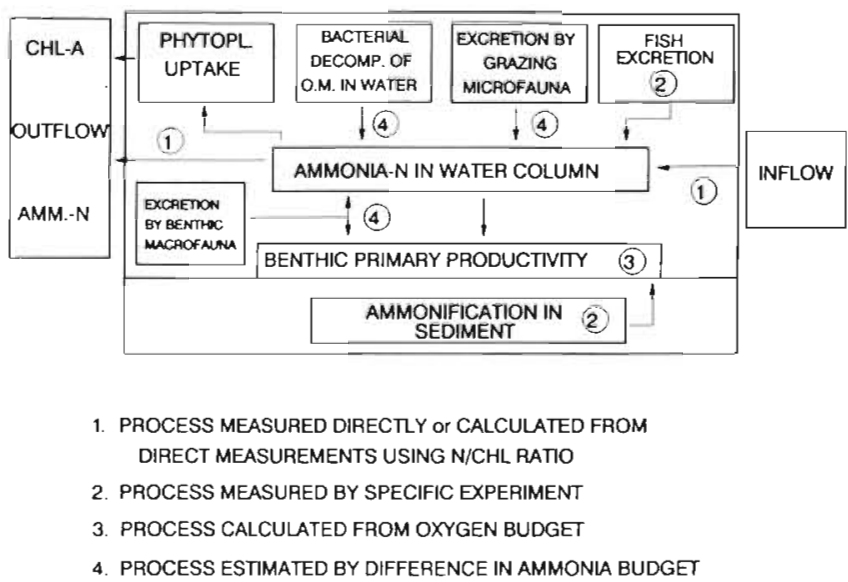

Fig. 3. Conceptual model used showing the major processes considered in the ammonia- $\mathrm{N}$ budget of the pond and how they were determined in this system 
Table 2. Sources and sinks of ammonia- $\mathrm{N}$ in the pond during phytoplankton crash period (6 to 24 March 1986). All results are given in mmol $\mathrm{N} \mathrm{m}^{-2} \mathrm{~d}^{-1}$ using a pond area of $325 \mathrm{~m}^{2}$

\begin{tabular}{|lccc|}
\hline $\begin{array}{l}\text { Inputs to pond } \\
\text { Inflow }\end{array}$ & $\begin{array}{c}\text { Excretion } \\
\text { by fish }\end{array}$ & $\begin{array}{c}\text { Bacterial } \\
\text { breakdown of } \\
\text { organic matter } \\
\text { in sediment }\end{array}$ & $\begin{array}{c}\text { Excretion by } \\
\text { macro- + micro- } \\
\text { fauna + micro- } \\
\text { bial respiration } \\
\text { in water column }\end{array}$ \\
\hline $0.28 \pm 0.04$ & $2.97 \pm 0.30$ & $16.09 \pm 3.32$ & $12.86 \pm 4.09$ \\
$\begin{array}{l}\text { Sinks within pond } \\
\text { Outflow }\end{array}$ & $\begin{array}{c}\text { Phytoplankton } \\
\text { uptake }\end{array}$ & $\begin{array}{c}\text { Uptake by } \\
\text { benthic algae }\end{array}$ \\
\hline $0.85 \pm 0.13$ & $1.63 \pm 0.18$ & $29.72 \pm 2.37$ \\
\hline
\end{tabular}

$20 \%$ (i.e. 0.52 to $0.76 \mu \mathrm{mol} \mathrm{N} / \mu \mathrm{g}$ chl a) then the net removal rate of ammonia- $\mathrm{N}$ from the pond would change from $1.63 \mathrm{mmol} \mathrm{N} \mathrm{m}{ }^{-2} \mathrm{~d}^{-1}$ to either 1.32 or 1.93 mmol $\mathrm{N} \mathrm{m}^{-2} \mathrm{~d}^{-1}$.

The excretion rate of ammonia by fish and the rate of ammonification in the sediment were determined by specific experiments. It has been shown that Sparus aurata excrete $30 \%$ of the $\mathrm{N}$ in this particular fish food as ammonia- $N$ into the water column (Porter et al. 1987). No similar measurements have been made of the excretion rate of Mugilidae. As an estimate for this comparatively small term in the budget, it was assumed that the excretion rate of Mugilidae was similar to that of $S$, aurata and hence the value of ammonia excreted determined from amount of $\mathrm{N}$ in the food supplied ( $813 \mathrm{mmol} N$ pond $\mathrm{d}^{-1} \mathrm{~d}^{-1}$ ) was increased by a factor of 1.2 , the ratio of $S$. aurata biomass to total fish biomass at the time of the study, to 966 mmol $\mathrm{N}$ pond ${ }^{-1} \mathrm{~d}^{-1}\left(2.97 \mathrm{mmol} \mathrm{N} \mathrm{m}^{-2} \mathrm{~d}^{-1}\right)$. No errors can be estimated directly for this term. The error given in Table 2 of $\pm 10 \%$ is intended to provide an estimate to show the relative unimportance of this term in the overall budget.

As has been argued above (within the nitrate budget calculations), nitrification of ammoniun to nitrate was an insignificant process within the pond system at this time.
The rate of ammonia- $N$ released from the bacterial breakdown of organic matter in the sediment of this pond was determined directly both from sediment incubation experiments and using the measured sulphate reduction rate and a factor of 7.93 to convert the rate to nitrogen equivalents (Blackburn et al. 1988). The resultant rate of ammonification in the sediment was 16.1 (13.4 to 18.8 ) $\mathrm{mmol} \mathrm{N} \mathrm{m}^{-2} \mathrm{~d}^{-1}$. This was the net ammonia production after the ammonia produced equilibrated with the sediment. The source of the easily degraded organic matter included fish faeces, sedimented planktonic material, and benthic organic matter.

Having solved the ammonia budget to this point, it was found that there was considerably more ammonia$N$ supplied to the pond than could be accounted for in the outflow + phytoplankton uptake. One potential sink for ammonia- $\mathrm{N}$ in the system was benthic primary productivity.

The dissolved oxygen budget has been used to determine the total community metabolism of the pond during bloom periods (Erez et al. 1990). The community gross photosynthesis (CGP) and community respiration (CR) were calculated on several days during the crash period (CGP: 7 March, 9 March, and 11 March; CR: $6-7,9-10,10-11$, and 11-12 March). The results are given in Table 3 with the errors given being the calculated standard error of the mean.

The gross photosynthesis and respiration of the water column measured by light/dark bottles are also given in Table 3. These parameters were measured only once during the crash period (6 March). They were measured 3 times within a period of $5 \mathrm{~d}$ during the bloom period (Erez et al. 1990). The errors given in Table 3 were calculated assuming the relative error (percentage of the value determined) was the same on both occasions. As an independent check on this value, the net system productivity of the water column was also estimated from the measured chlorophyll $a$ in the water column by assuming that, at steady-state, the amount of chlorophyll exported from the pond each day is equal to the net productivity. Using this procedure, a C:chl ratio of $4.2 \mu \mathrm{mol} \mathrm{C} / \mu \mathrm{g} \mathrm{chl}$ a and a photosynthetic quotient of 1.25 (Williams et al. 1979), the

Table 3. Integrated daily rate of gross photosynthesis and respiration for the pond ecosystem during phytoplankton crash period (6 to 24 March 1986). All values are given in mmol $0 \mathrm{~m}^{-2} \mathrm{~d}^{-1}$ using $325 \mathrm{~m}^{2}$ for the pond area

\begin{tabular}{|c|c|c|c|c|c|}
\hline \multicolumn{2}{|c|}{$\begin{array}{c}\text { Total community } \\
\text { (calculated directly) }\end{array}$} & \multicolumn{2}{|c|}{$\begin{array}{l}\text { Water column } \\
\text { (measured directly) }\end{array}$} & \multicolumn{2}{|c|}{$\begin{array}{c}\text { Benthir } \\
\text { (calculated by difference) }\end{array}$} \\
\hline $\begin{array}{l}\text { Gross } \\
\text { production }\end{array}$ & Respiration & $\begin{array}{l}\text { Gross } \\
\text { production }\end{array}$ & Respiration & $\begin{array}{c}\text { Gross } \\
\text { production }\end{array}$ & Respiration \\
\hline $283 \pm 19$ & $305 \pm 29$ & $37 \pm 3$ & $28 \pm 9$ & $246 \pm 19.7$ & $255^{\alpha} \pm 31$ \\
\hline
\end{tabular}


calculated net productivity was $13.5 \mathrm{mmol} O \mathrm{~m}^{-2} \mathrm{~d}^{-1}$ This is similar to the net productivity of $9 \mathrm{mmol} \mathrm{O}$ $\mathrm{m}^{-2} \mathrm{~d}^{-1}$ measured directly. The water column respiration includes both phytoplankton respiration and other heterotrophic microbial respiration in the water column. The benthic gross productivity was the total system productivity minus the water column productivity.

In order to calculate the benthic respiration, it was necessary to correct for the effect of fish respiration. Two independent methods were used for this estimate. Using laboratory estimates for the standard metabolic rate of Sparus aurata, Erez et al. (1990) estimate the fish respiration rate in the pond to be $2.2 \mathrm{~mol} O$ pond ${ }^{-1} \mathrm{~d}^{-1}$. An alternative procedure is to assume that all the food given to the fish is used in growth, excretion of DOM and respiration. Since one of the end products of respiration by these types of fish is ammonia$N$, it is possible to calculate the amount of oxygen consumed by fish respiration from the amount of ammonia-N excreted using an $\mathrm{O}: \mathrm{N}$ molar ratio of $106: 16$, a value of $6.5 \mathrm{~mol} O$ pond ${ }^{-1} \mathrm{~d}^{-1}$ was obtained. This estimate was used to correct the values given in Table 3. Whichever estimate is used however, the correction due to this factor was relatively small.

The uptake of ammonia- $\mathrm{N}$ by benthic algae (Table 2) was then calculated from the benthic productivity (80 mol O pond ${ }^{-1} \mathrm{~d}^{-1} ; 246 \mathrm{mmol} O \mathrm{~m}^{-2} \mathrm{~d}^{-1}$ ) assuming a Redfield C:N ratio of $106: 16$ and a photosynthetic quotient of 1.25 . While it is known that the $\mathrm{C}: \mathrm{N}$ ratio of macroalgae can vary over a large range, experimental studies on Ulva sp. grown in fishpond effluent in Eilat have a ratio in the range 5 to 7 when grown in high concentrations of ammonia-N (Neori unpubl.). At

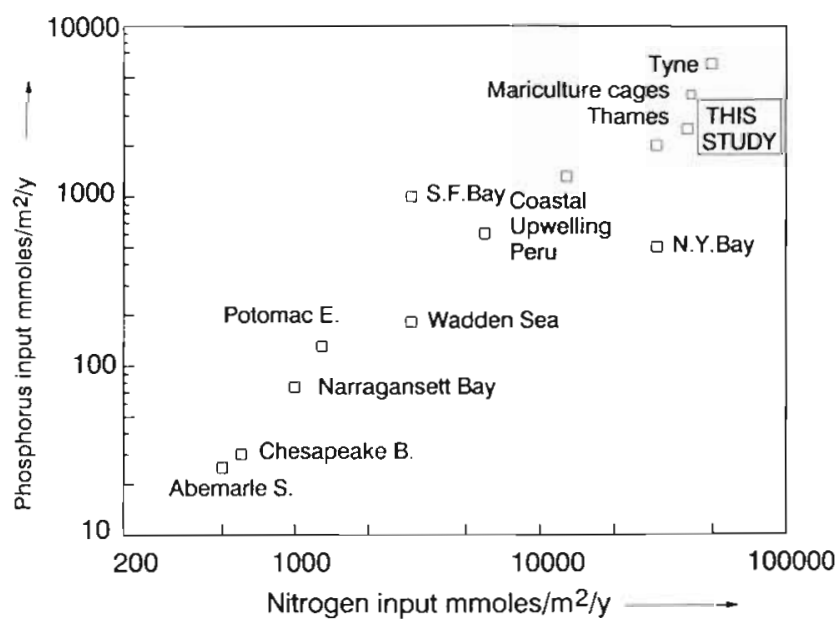

Fig. 4. Approximate annual input of nitrogen and phosphorus per unit area to a number of marine and estuarine systems including the data from this study as a measure of the relative degree of eutrophication. (Figure based on that from Nixon et al. 1986) lower concentrations of ammonia- $N$, the $C: N$ ratio increases to values of 14 to 16 or more.

Excretion of ammonia- $\mathrm{N}$ by benthic macro- and microfauna was calculated by difference. The value of $12.86 \mathrm{mmol} \mathrm{N} \mathrm{m}^{-2} \mathrm{~d}^{-1}$ is considered a maximum and would be lower if the actual $\mathrm{C}: \mathrm{N}$ ratio of the benthic algae (micro and macro) was higher than the 5 to 7 value used in the calculation.

An ammonia- $\mathrm{N}$ budget was not calculated during the bloom period because it was known that uptake by phytoplankton was relatively a more important process (Krom et al. 1989). The errors in the total budget caused by uncertainties in the N:chl ratio, which were relatively minor in this study, became unacceptably high.

\section{DISCUSSION}

The pond is hypertrophic as defined by Barica \& Mur (1979). It is supplied with high levels of dissolved nutrients from the inflow and from fish food - so high that it is comparable to the most nutrient-rich marine systems, the Thames and Tyne estuaries in the UK, and somewhat greater than the inputs to New York Bay and the coastal area off Peru (Fig 4; Nixon et al. 1986). The input of nutrients is also comparable to that found in many smaller local areas such as those close to sewage outfalls (Bascom et al. 1979) and beneath mariculture seacages (Hall et al. 1990, Aure \& Stigebrandt 1990) or mussel rafts (Tenore et al. 1982). Although the sediments beneath this pond are comparatively low in organic carbon $(1.1 \%)$ the rate of organic matter turnover is extremely high (Blackburn et al. 1988)

The rate of microbial nitrate reduction in the sediment estimated in this study from the total pond budget during the phytoplankton crash period was $2.5 \pm 0.1 \mathrm{~mol} \mathrm{~N}$ pond $\mathrm{d}^{-1} \mathrm{~d}^{-1}$ which corresponds to $7.7 \pm$ $0.3 \mathrm{mmol} \mathrm{m} \mathrm{m}^{-2} \mathrm{~d}^{-1}$ over the entire area of the pond. This compares to the value of $6.0 \pm 1.5 \mathrm{mmol} \mathrm{m} \mathrm{m}^{-2} \mathrm{~d}^{-1}$ measured directly by Blackburn et al. (1988). During the crash period when free ammonia- $N$ and nitrate are available in the water column, nitrate reduction represents the most important process controlling the concentration of nitrate. Nitrification and uptake by phytoplankton during the crash period are relatively insignificant within this hypertrophic system (Blackburn et al. 1988; this study).

The breakdown of labile organic matter in the sediments represents the dominant source of ammonia- $N$ to the system (a minimum of $50 \%$ of the total input; Table 2 ). The fish themselves, despite the pond being operated as an experimental mariculture pond, have a rather small direct affect on the ammonia- $\mathrm{N}$ budget of 
the ecosystem $(10 \%$ of the total input). They are, however, the ultimate source of most of the particulate organic matter which is supplied to the sediment as uneaten food, faeces and sedimented planktonic material.

The principal source of ammonia- $N$ production in the sediment is from organic matter, ultimately oxidised by sulphate reduction (Blackburn et al. 1988). The rates of sulphate reduction in the sediment (mean value of $70 \mathrm{mmol} \mathrm{m}^{-2} \mathrm{~d}^{-1}$ ) are 3 times higher than that measured at the 'Black Hole' in Long Island Sound, USA, a highly polluted location receiving local sewage effluent, and 30 times higher than North West Control (NWC), a normal nearshore location in Long Island Sound (Westrich \& Berner 1989). The corresponding rates of ammonia- $\mathrm{N}$ production $\left(15 \mathrm{mmol} \mathrm{N} \mathrm{m}^{-2} \mathrm{~d}^{-1}\right.$ ) are high compared to 'normal' coastal marine systems such as Loch Ewe, Scotland (1.2 mmol $\mathrm{N} \mathrm{m}^{-2} \mathrm{~d}^{-1}$ ), Buzzards Bay, Massachusetts, USA $(2.9 \mathrm{mmol} \mathrm{N}$ $\left.\mathrm{m}^{-2} \mathrm{~d}^{-1}\right)$ or Narragansett Bay, Rhode Island, USA (4.8 mmol $\mathrm{N} \mathrm{m}^{-2} \mathrm{~d}^{-1}$; Nixon 1981). They are high even compared to polluted eutrophic systems such as the Patuxent River estuary, Chesapeake Bay, USA (12.5 mmol $\mathrm{N} \mathrm{m}^{-2} \mathrm{~d}^{-1}$; Nixon 1981).

Despite this high rate of production, most if not all of this ammonia- $N$ did not reach the water column. It was intercepted by the benthic flora - both seaweeds and epibenthic microalgae - and was used to support the high levels of benthic productivity observed in this system. Previous studies have suggested that benthic productivity may be important in modifying the flux of nutrients from pore waters to the water column in other shallow water marine systems such as Limfjorden (Fenriksen et al. 1980), W. Kattegat (Blackburn \& Henriksen 1983) and Potter Pond (Nowicki \& Nixon 1985a). In other studies, while no attempt was made to quantify this process directly, it has been suggested that otherwise unexplained results may be due to this process (e.g. parts of San Fransisco Bay: Hammond et al. 1985; parts of Saginaw Bay, Lake Huron: Ullman \& Aller 1989).

It has been estimated that $30 \%$ of the total sediment in Narragansett Bay is situated in waters which receive $1 \%$ of the incident light or greater (Chinman \& Nixon 1985. Pilson pers. comm.) and thus may have significant benthic productivity. Those authors who have attempted to quantify this effect used light/dark benthic chambers to measure this effect and thus concentrated on quantifying the effect of benthic microflora (e.g. Henriksen et al. 1980, Sundbäck \& Granéli 1988). However, Nixon (1982) showed that for a variety of shallow marine lagoons, macroalgal productivity is often at least as important as microfloral production. Similarly macroalgal productivity can be of considerable importance in shallow coastal regions such as those off South Carolina, USA (Calhoun \& Cooke 1990). In this ecosystem, substantial quantities of both benthic microalgae and pelagic macroalgae were found. While no direct attempt was made to quantify the relative importance of these 2 components on either benthic productivity or the flux of nutrients from the sediment into the overlying water, it is likely that both types of flora were important.

Hammond et al. (1985) noted that benthic fluxes of nutrients can be determined by use of benthic chambers, by incubation of cores in the laboratory, by use of pore water profiles together with Fick's law or by mass balance in the overlying water. They noted that use of mass balance was the least precise method because of problems in determining reactions and transport in the overlying water. Use of incubation cores in the laboratory and pore water profiles alone (Blackburn et al. 1988) suggested the sediments were a major source of ammonia-N directly to the water column. This study showed that the use of total nutrient budgets, despite the errors inherent in such calculations, was necessary to show the importance of benthic micro- and macroalgae in controlling the flux of nutrients from the sediment to the overlying water.

\section{SUMMARY}

The amount of nitrate present in the water column of this hypertrophic marine system during the period of a phytoplankton crash was controlled by microbial nitrate reduction in the surficial sediments. The rate of this nitrate reduction was calculated using a total nutrient budget of the pond system as a whole and also by specific experiments on subcores taken from the system. The rates measured directly on these subcores $\left(6.0 \pm 1.5 \mathrm{mmol} \mathrm{m} \mathrm{m}^{-2} \mathrm{~d}^{-1}\right)$ were similar to the value calculated from a whole pond nutrient budget $7.7 \pm$

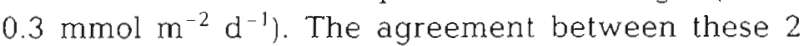
independent procedures supports the assumptions made in the total nutrient budget were valid. Previous studies on this pond system have shown that the principal control on the nitrate (and ammonia) concentration during the bloom periods was by phytoplankton uptake.

The budget for ammonia- $N$ was more complex than that for nitrate. The results showed that organic matter breakdown in the sediments represented the dominant source of ammonia- $N$ to the system (16.09 mmol $\mathrm{m}^{-2} \mathrm{~d}^{-1}$ ) compared to $2.97 \mathrm{mmol} \mathrm{m}^{-2} \mathrm{~d}^{-1}$ directly from fish excretion and $0.28 \mathrm{mmol} \mathrm{m} \mathrm{m}^{-2} \mathrm{~d}^{-1}$ in the inflow. Despite this high rate of production in the sediment, most, if not all, this ammonia- $N$ did not reach the water column but was intercepted by the benthic flora and used to support high levels of benthic productivity 
(246 mmol O m-2 $\mathrm{d}^{-1} ; 29.72 \mathrm{mmol} \mathrm{N} \mathrm{m}^{-2} \mathrm{~d}^{-1}$ ).

While this system is an extreme example of a hypertrophic body of water, it is on a continuum with other polluted and natural coastal marine systems. It is suggested here that benthic productivity by micro- and macroalgae may be important in a number of such shallow marine systems as modifiers of the flux of ammonia- $N$ from the sediment to the overlying waters. This study showed that the use of total nutrient budgets (nitrate, ammonia- $\mathrm{N}$ and dissolved oxygen), despite the errors inherent in such calculations, enabled me to show the importance of benthic microand macroalgae in controlling the flux of nutrients from the sediment to the overlying water while simple measurements using Fick's 1st law and laboratory flux studies missed this dominant process.

Acknowledgements. I thank A. Davidson and D. Malachi for their help with sampling and analysis and $C$. Porter for maintaining the fishponds throughout this period. I also thank the $\mathrm{H}$. Steinitz Marine Laboratory for the use of their laboratory and other facilities. This paper benefited greatly from the input of $\mathrm{H}$. Gordin, H. Blackburn, J. Erez, S. Ellner, A. Neori, S. Nixon, B. Nowicki, M. E. Q. Pilson and by 3 anonymous reviewers at various stages in its development. The manuscript was written while I was on sabbatical leave at the University of Rhode Island and I thank R. Duce and M. E. Q. Pilson for their generous use of the facilities of URI. This work was supported by BARD research grant no. I-62683 and the Israel Ministry of Energy and Infrastructure Mariculture project.

\section{LITERATURE CITED}

Asmus, R. (1986). Nutrient flux in short-term enclosures of intertidal sand communities. Ophelia 26: 1-18

Aure, J., Stigebrandt, A. (1990). Quantitative estimates of the eutrophication effects of fish farming on fjords. Aquaculture 90(2): 135-156

Barica, J., Mur, L. R. (1979). Hypertrophic ecosystems. Developments in hydrobiology, Vol 2. Dr W. Junk, The Hague

Bascom, W., Brooks, N., Eppley, R., Hendricks, T., Knauer, G., Pritchard, D., Sherwood, M., Word, J. (1979). Southern California Bight. In: Goldberg, E. D. (ed.) Assimilative capacity of U. S. coastal waters for pollutants. U. S. Dept. of Commerce, p. 179-242

Berman, T., Sherr, B. F., Sherr, E., Wynne, D., McCarthy, J. J (1984). The characteristics of ammonium and nitrate uptake by phytoplankton in Lake Kinneret. Limnol. Oceanogr. 29: $287-297$

Billen, G. (1978). A budget of nitrogen recycling in North Sea sediments off the Belgian coast. Estuar. coast. Shelf Sci. 7 : $127-146$

Blackburn, T H., Henriksen, K. (1983). Nitrogen cycling in different types of sediments from Danish waters. Limnol. Oceanogr. 28 (3): 477-493

Blackburn, T H., Lund, B. A., Krom, M. D. (1988). C- and Nmineralization in seawater fish pond sediments. Mar. Ecol. Prog. Ser. 44: 221-227

Cahoon, L. B., Cooke, J. E. (1990). The importance of benthic microalgal production in a continental shelf ecosystem. ASLO summer meeting, VIMS, Virginia
Chinman, R. A., Nixon, S. W. (1985). Depth-area-volume relationships in Narragansett Bay. NOAA Sea Grant mar. Tech. Rep. 87

Ellner, S. E., Krom, M. D., Brauer F. (1988). Modelling and management for seawater fishponds. In: Hallem, $T$ G., Gross, L. J., Levin, S. A. (eds.) Proc. of the Trieste Research Conference on Mathematical Ecology, Trieste 1986. World Scientific, Singapore, p. 215-236

Erez, J., Krom, M. D., Neubirt, T (1990). Daily oxygen variations in marine fish ponds, Eilat, Israel. Aquaculture 84 (3/4): 289-306

Glibert, P. L., Loder, T S. (1977). Automated analysis of nutrients in seawater: a manual of techniques. Woods Hole Oceanogr. Inst. Tech. Rep. WHOI-77-47

Goldman, J. C. (1976). Identification of nitrogen as a growth limting nutrient in wastewater and coastal marine waters through continuous culture algal assays. Water Res. 10: $97-104$

Hall, P. O. J., Anderson, L. G., Holby, O., Kollberg, S., Samuelsson, M. O. (1990). Chemical fluxes and mass balances in a marine fish cage farm. I Carbon. Mar. Ecol. Prog. Ser. 61: 61-73

Hammond, D. E., Fuller, C., Harmon, D., Hartman, B., Korasec, M., Miller, L. G., Rea, R., Warren, S., Berelson, W., Hager, S. W. (1985). Benthic fluxes in San Fransisco Bay. Hydrobiologia 129: 69-90

Henriksen, K., Hansen, J I., Blackburn, T. H. (1980). The influence of benthic infauna on exchange rates of inorganic nitrogen between sediment and water. Ophelia Suppl. 1. 249-256

Krom, M. D. (1986). Sources of water to the seawater well which supplies the fish ponds in Eilat: implications for pond management. Water Res. 20(4): 463-469

Krom, M. D., Erez, J., Porter, C. B., Ellner, S. (1989). Phytoplankton nutrient uptake dynamics in earthen marine fishponds under winter and summer conditions. Aquaculture 76: 237-253

Krom, M. D., Grayer S., Davidson A. (1985b). An automated method of ammonia determination for use in mariculture. Aquaculture 44: 153-160

Krom, M. D., Porter, C., Gordin, H. (1985a). Nutrient budget of a marine fish pond in Eilat, Israel. Aquaculture 51: $65-80$

Mackin, J. E., Swider, K. T (1989). Organic matter decomposition pathways and oxygen consumption in coastal marine sediments. J. mar. Res. 47: 681-716

Motzkin, F., Cohen, Y., Gordin, H., Padan, E. (1982). Productivity relations in seawater fish ponds: a comparison of stocked and unstocked ponds. Mar. Ecol. Prog. Ser 8: $203-210$

Nixon, S. W. (1981). Remineralization and nutrient cycling in coastal marine ecosystems. In: Neilson, B. J., Cronin, L. E. (eds.) Estuaries and nutrients. Humana Press, Clifton, New Jersey, p. 111-137

Nixon, S. W. (1982). Nutrient dynamics, primary production and fisheries yields of lagoons. Proc. Int. Symp. on coastal lagoons SCOR/IABO/UNESCO, Bordeaux 8-14 Sept. 1981. Oceanol. Acta, p. 357-371

Nixon, S. W., Oviatt, C. A., Frithsen, J., Sullivan, B. (1986). Nutrients and the productivity of estuaries and coastal marine ecosystems. J. Limnol. Soc. S. Afr. 12(1/2): 43-71

Nixon, S. W., Oviatt, C. A., Hale, S. S. (1975). Nitrogen regeneration and the metabolism of coastal marine bottom communities. In: Anderson, J. M., MacFadyen, A. (eds.) The role of terrestrial and aquatic organisms in decomposition processes. 17th Symp. Br. Ecol. Soc. 15-18 April 1975. Blackwell Sci. Publ., Oxford, p. 269-285 
Nowicki, B. L., Nixon, S. W. (1985a). Benthic nutrient remıneralization in a coastal lagoon ecosystem. Esturtries 8 (2B): $182-190$

Nowicki, B. L., Nixon, S. W. (1985b) Benthic community metabolism in a coastal. lagoon ecosystem. Mar. Ecol. Prog. Ser 22: 21-30

Odum, H. T (1956). Primary production in flowing waters Limnol. Oceanogr. 1: 102-117

Olah, J., Zsigri, A., Kintzly, A. V. (1978). Primary production estimations in fishponds by mathematical evaluation of daily $\mathrm{O}_{2}$ curves. Aquacultura Hungarica (Szarvas) 1: 3-14

Parson, T R., Takahashi, M., Hargrave, B. (1984). Biological. oceanographic processes, 3rd edn. Pergamon Press, Oxford.

Porter, C. P., Krom, M. D., Robbins, M. G., Bricknell, L., Davidson A. (1987). Ammonia excretion and total $N$ budget for gilthead seabream (Sparus aurata) and its effect on water quality conditions. Aquaculture 66: $287-298$

Rimon, A., Shilo, M. (1982). Factors which affect the intensification of fish breeding in Israel. 2. Ammonia transformation in intensive fish ponds. Bamidgeh 34: 101-114

Strickland, J. D. H., Parsons, T R. (1972). A practical hand-

This article was submitted to the editor book of seawater analysis, 2nd edn. Bull. Fish. Res. Bd Can. 167

Sundbäck, K., Granéli, S. (1988). Influence of microphytobenthos on the nutrient flux between sediments and water: a laboratory study. Mar. Ecol. Prog. Ser. 43: 63--69

Tenore, K. R., Boyer, L. F., Cal, R. M., Corral, J., GarciaFernandez, C., Gonzalez, N., Gonzalez-Gurriaran, E., Hanson, R. B., Iglesias, J., Krom, M., Lopez-Jamar, E., McClain, J., Pamatmat, M. M., Perez, A., Rhoads, D. C., de Santiago, G., Tietjen, J., Westrich, J., Windom, H. L. (1982). Coastal upwelling in the Rias Bajas, NW Spain: Contrasting the benthic regimes of the Rias de Arosa and de Muros. J. mar. Res. 40(3): 701-772

Ulman, W. J., Aller, R. C. (1989). Nutrient release rates from the sediments of Saginaw Bay, Lake Huron. Hydrobiologia 171: 127-140

Westrich, J., Berner, R. A. (1988). The effect of temperature on rates of sulphate reduction in marine sediments. Geomicrobiol. J. 6: 99-117

Williams, P J. LeB., Raine, R. C. T., Bryan, J. R. (1979). Agreement between the $\mathrm{C}-14$ and oxygen methods of measuring phytoplankton production: reassessment of the photosynthetic quotient. Oceanol. Acta 2 (4): 411-416

Manuscript first received: December 10, 1990

Revised version accepted: October 24, 1991 